\title{
Impact of Milking Frequencies on the Level of Free Fatty Acids in Milk, Fat Globule Size, and Fatty Acid Composition
}

\author{
L. Wiking, ${ }^{\star 1}$ J. H. Nielsen, ${ }^{\star}$ A.-K. Båvius, $†$ A. Edvardsson, $†$ and K. Svennersten-Sjaunja† \\ *Department of Food Science, Danish Institute of Agricultural Sciences, Research Centre Foulum, DK-8830 Tjele, Denmark \\ †Department of Animal Nutrition and Management, Kungsängens Research Centre, Swedish University of Agricultural Sciences, \\ 75323 Uppsala, Sweden
}

\section{ABSTRACT}

The aim of the present study was to study the effect of milking cows 4 times daily on free fatty acids (FFA) in the milk compared with milking twice daily. An experiment was performed during 2 wk in which half udders in 11 cows were milked 2 or 4 times daily. Milk yield was measured, and milk was analyzed for fat content, FFA, fatty acid composition, fat globule size, and activity of $\gamma$-glutamyl transpeptidase. Concentration of FFA was greater $(1.49 \mathrm{mEq} / 100 \mathrm{~g}$ of fat) in milk from half udders milked 4 times daily than in milk from the half udders milked twice daily $(1.14 \mathrm{mEq} / 100 \mathrm{~g}$ of fat). Further, it was noted that milk from the half udder milked 4 times daily contained milk fat globules with larger average diameters. Increased milking frequency increased milk yield by $9 \%$ compared with the udder half milked twice daily, but fat content and fat yield were not affected. The results are of importance for further understanding the mechanisms behind the increased content of FFA that is frequently observed in automatic milking systems.

Key words: milking frequency, free fatty acid, milk fat globule, milk fat globule membrane

\section{INTRODUCTION}

When milk producers invest in automatic milking systems, one incentive is an expectation of increased milk production per cow caused by increased milking frequency. Furthermore, more dairy producers using conventional systems are milking 3 times daily. It has been reported that increasing milking from 2 to $\geq 3$ times daily will increase the milk yield by up to $18 \%$ (Stelwagen, 2001). Today, about 5\% of total bulk milk in Denmark, Sweden, and The Netherlands originates from automatic milking systems, and the proportion is continuously increasing. The drawback, however, is that the concentration of FFA in milk from automatic

Received May 9, 2005.

Accepted October 28, 2005.

${ }^{1}$ Corresponding author: lars.wiking@agrsci.dk milking systems is greater than that in milk from conventional systems (Justesen and Rasmussen, 2000; Klungel et al., 2000; de Koning et al., 2003; Pirlo et al., 2004). Greater FFA in automatic milking systems could be due to increased milking frequency, because increased milking frequency has been shown to increase FFA content in milk (Klei et al., 1997, Wiktorsson et al., 2000; Svennersten-Sjaunja et al., 2002; Slaghuis et al., 2004). Elevated amounts of FFA can result in rancid flavors in dairy products (Tuckey and Stadhouders, 1967; Shipe et al., 1980). Furthermore, the amount of FFA in raw milk is correlated positively with the fat loss in whey during cheese production (Sapru et al., 1997).

Accumulation of FFA in raw milk originates from hydrolysis of the triglycerides catalyzed by mainly lipoprotein lipase $(\mathbf{L P L})$. The LPL originates from the mammary gland, where it is involved in the uptake of blood lipids for milk lipid synthesis. Despite a high amount of LPL in milk, lipolysis is limited because triglycerides in the milk fat globule (MFG) are protected by the surrounding membrane. The MFG membrane (MFGM) is composed of phopholipids, cholesterol, lipoproteins, glycoproteins, and proteins (e.g., xantine oxidase, butyrophillin, and $\gamma$-glutamyl transpeptidase; Evers, 2004).

Milk fat is synthesized as globules in the secretory cells of the mammary glands. At the surface of endoplasmic reticulum, the lipid is synthesized. These microlipid droplets are released into the cytoplasm with a surface of protein and polar lipids (Mather and Keenan, 1998). On their way to the apical cytoplasm, they fuse and, thereby, increase in size. The MFG are released from the secretory cells into milk through the apical plasma membrane. There, they are covered by an outer bilayer membrane. Between milkings, milk is stored in the lumen of alveoli, milk ducts, and udder cisterns. With regular milking of dairy cows twice daily, the proportion of cisternal milk is $<30 \%$ of total milk yield (Bruckmaier et al., 1994; Ayadi et al., 2003), and fat content is lesser in cisternal milk than in alveolar milk (Ayadi et al., 2004). With irregular milkings (e.g., 8- to 16-h milking intervals), a larger proportion of the milk is stored in the cisternal cavities at longer milking inter- 
vals compared with shorter intervals. At shorter milking intervals, usually at evening milkings, milk fat content as well as content of FFA are also greater (Ahrné and Björck, 1985).

The objectives of the present study were to study the impact of 4 times vs. 2 times daily milking on the FFA content in milk, measured both at morning and evening milkings and, furthermore, to elucidate the mechanisms responsible for changes in the amount of FFA as milking frequency increased.

\section{MATERIALS AND METHODS}

\section{Animals and Sampling}

The experiment was carried out at Kungsängen Research Center at The Swedish University of Agricultural Sciences in Uppsala. In total, 11 cows from the experimental herd of Swedish Red and White cows were used in the study. Cows were between 11 and 55 wk of lactation. They were housed in tie stalls and milked with a specially designed milking machine for milking and sampling from each separate udder quarter. The air inlet in the milking machine was similar to an automatic milking system. The teats were dried with a wet paper towel, and control milk was removed from each individual quarter before the milking claw was attached. Prestimulation lasted for an average of 30 to $60 \mathrm{~s}$. Once milked, the milking claw was detached manually. The teats were dipped in disinfectant solution after milking. The cows were fed 4 times daily at $0600,1000,1200$, and $1600 \mathrm{~h}$. They were fed silage ad libitum, $1 \mathrm{~kg}$ of hay, and concentrate according to milk yield to meet $60 \mathrm{MJ}$ of $\mathrm{ME}$ for maintenance and $5 \mathrm{MJ}$ of ME/kg of ECM (Sjaunja et al., 1990).

The experimental design was a half-udder design with 2 periods. Each period lasted $5 \mathrm{~d}$. During the first period, each udder half was milked twice daily at 0600 and $1800 \mathrm{~h}$. During the second period, one udder half was milked twice daily at 0600 and $1800 \mathrm{~h}$, and the opposite udder half was milked 4 times a day at 0600 , 1200,1800 , and 2400 . One-half of the cows was chosen randomly to be milked more frequently on the right udder part, and the other half of the cows was milked more frequently on the left udder half. Milk yield was measured, and milk samples for analyses of fat content were collected at each milking on $\mathrm{d} 3$ and 5 during both periods. Samples were collected for analyses of fatty acid composition and fat globule size at 0600 and 1800 h. Samples to measure $\gamma$-glutamyl transpeptidase were collected only on d 5 of each period. Two identical samples for FFA were collected on d 5 of each period at 0600 and $1800 \mathrm{~h}$ from each separate udder half. The first sample was directly placed in tubes containing an extraction and lipolytic inhibiting solution, whereas the second sample was stored at $5^{\circ} \mathrm{C}$ for $24 \mathrm{~h}$ before the extraction solution was added because it is more common to compare the amount of FFA after $24 \mathrm{~h}$ of storage. Milk samples for FFA analyses were stored frozen $\left(-20^{\circ} \mathrm{C}\right)$ until analyzed.

\section{Analysis of Fat Content}

Milk fat was analyzed by using the mid infrared spectroscopy method (FT120, Foss Electric, Hillerød, Denmark).

\section{Analysis of FFA in Milk}

The FFA content was analyzed by using the Autoanalyzer II method (Lindqvist et al., 1975). The method is based on an extraction of milk using an extraction and lipolytic inhibiting solution containing 2-propanol, heptane, and $1 \mathrm{~N} \mathrm{H}_{2} \mathrm{SO}_{4}$. Using this method, lipoprotein lipase is in the aqueous phase, and the lipids are separated. In the autoanalyzer, the solution is mixed with the indicator reagent (phenol red, sodium barbital, and ethanol). Finally, absorbance is recorded at $560 \mathrm{~nm}$ in a colorimeter. The results are expressed in meq/100 g of fat. The Autoanalyzer II method has a greater recovery of short-chain fatty acids than the BDI (Bureau of Dairy Industries) method (IDF, 1991).

\section{Determination of the Particle Size Distribution of MFG}

Particle size distribution of MFG was determined by laser light scattering as previous described by Wiking et al. (2003). The volume-weighted diameter, $d_{(4,3)}(\mu \mathrm{m})$, was calculated by the integrated software together with $\mathrm{D}(0.1)$ and $\mathrm{D}(0.9)$, which are the 10 and $90 \%$ percentiles, respectively.

\section{Fatty Acid Composition in Milk}

Fatty acid composition of the milk fat was determined by gas chromatography separation and quantification as described by Wiking et al. (2003).

\section{Assay for $\gamma$-Glutamyl Transpeptidase Activity}

Activity of $\gamma$-glutamyl transpeptidase in whole raw milk was quantified according to Wiking et al. (2004).

\section{Statistical Analysis}

All data were statistically evaluated using a paired $t$-test. 
Table 1. Concentration of FFA during the control period and the following period with different milking frequencices per half udder ${ }^{1}$

\begin{tabular}{llcl}
\hline $\begin{array}{l}\text { Time of } \\
\text { collection }^{2}\end{array}$ & $\begin{array}{l}\text { Control period } \\
(2 \times \text { milking })\end{array}$ & $2 \times$ milking & $4 \times$ milking \\
\hline & & $(\mathrm{mEq} / 100 \mathrm{~g}$ of fat $)$ & \\
\cline { 2 - 4 } $0 \mathrm{~h}$ & $0.68^{\mathrm{a}}(0.02)$ & $0.72^{\mathrm{ab}}(0.03)$ & $0.76^{\mathrm{b}}(0.04)$ \\
$24 \mathrm{~h}$ & $1.21^{\mathrm{ab}}(0.08)$ & $1.14^{\mathrm{a}}(0.09)$ & $1.49^{\mathrm{b}}(0.15)$ \\
\hline
\end{tabular}

${ }^{\mathrm{a}, \mathrm{b}}$ Values within a row without a common superscript letter differ $(P<0.01)$.

${ }^{1}$ Values are means (SE) for 11 cows.

${ }^{2}$ Concentration of FFA at $0 \mathrm{~h}$ is that immediately after milking, and FFA at $24 \mathrm{~h}$ is that $24 \mathrm{~h}$ after milking.

\section{RESULTS AND DISCUSSION}

\section{FFA}

Content of FFA immediately after milking $(0 \mathrm{~h})$ did not differ in milk from the udder half milked 2 vs. 4 times daily (Table 1). In contrast, FFA content in the milk obtained from cows during the control period was less $(P<0.01)$ than FFA content in the milk from the half udder milked 4 times daily. After $24 \mathrm{~h}$ of storage at $5^{\circ} \mathrm{C}$, FFA content was greater $(P<0.01)$ in the milk from the udder half milked 4 times daily than in the milk from other udder half milked twice daily.

Other studies have reported elevated concentrations of FFA after more frequent milkings. Klei et al. (1997) observed more FFA in milk from cows milked 3 times daily than that in milk from cows milked twice daily during early and midlactation. Similarly, Slaghuis et al. (2004) reported more FFA after increased milking frequencies (i.e., 2,3 , and 6 times daily). In contrast to the mentioned studies, half udder techniques were used in the present study to elucidate whether local mammary factors, and not systemic factors, have a major influence on FFA, because the whole udder has the same nutritional and endocrine environment. Using a similar half udder technique in a small study with 2 cows and 1 experimental day, Jellema (1986) observed a greater concentration of FFA in milk from the udder half milked 3 times daily compared with the udder half milked twice daily.

The present study indicates that a weakness in the MFG or MFGM causes the increase in amount of FFA after increased milking frequency, because the largest difference in FFA content in the milk from the 2 different milking frequencies was detected after 24-h storage at $5^{\circ} \mathrm{C}$. Similar results have been reported (Svennersten-Sjaunja et al., 2002; Slaghuis et al., 2004). The fact that a time-dependent increase in FFA content in milk occurred tends to reject the theory that more frequent milking is associated with insufficient triglyceride synthesis. Raw milk is stored normally 2 to $3 \mathrm{~d}$ in the farm bulk tanks. The increase in FFA is greatest during the first $24 \mathrm{~h}$ of storage (Wiking et al., 2002). Furthermore, the present study clearly demonstrates that elevated amounts of FFA had already occurred by $5 \mathrm{~d}$ after milking frequency was increased. Lipolysis in milk is also affected by stimulators and inhibitors of LPL (Cartier et al., 1990). Amount of stimulators and inhibitors was not determined in the present study. The stimulator apo-lipoprotein CII, however, is associated with blood, but no evidence exists for greater amounts of blood in milk upon more frequent milking.

Conflicting results exist concerning how different milking intervals (2 times daily milking) affect lipolysis in milk. Greater amounts of FFA have been found in milk when shorter intervals between milkings ( 8 to $9 \mathrm{~h}$ since the previous milking) were compared with longer intervals (15 to $16 \mathrm{~h}$ since the previous milking; Suhren et al., 1981; Ahrné and Björck, 1985). In contrast, others (O'Brien et al., 1998) did not detect significant differences in FFA content after unequal milking intervals.

\section{Milk Yield and Fat Content}

The short-term effects on milk yield and fat percentages of half udder milking with increasing milking frequencies are summarized in Table 2. Milk yield was greater $(P<0.05)$ from the udder half milked 4 times daily compared with the other half, which was milked twice daily. At $\mathrm{d} 5$ after initiating more frequent milking of the half udder, however, no differences were detected in fat yield or fat percentage after milking frequency was increased after 3 or $5 \mathrm{~d}$.

By using the same half udder milking technique, Knight et al. (1992) reported that milk yield increased by $14 \%$ after milking 4 times daily compared with twice daily milking. Hillerton et al. (1990) also observed a $10.4 \%$ increase in milk from the udder half that was milked 4 times daily compared with twice daily. In the present study, milk yield increased by an average of 9\%. In a long-term study, Klei et al. (1997) reported that fat yield produced by cows milked 3 times daily throughout the entire lactation was $4.7 \%$ greater than that from cows milked twice daily.

\section{MFG Size}

Milk from the half udder milked 4 times daily contained MFG with a larger $(P<0.001)$ average diameter $\left(\mathrm{d}_{(4,3)}\right)$ compared with milk from the udder half milked 2 times daily (Table 3$)$. The $\mathrm{D}(0.1)$ of the MFG was unaffected by milking frequency, whereas the $\mathrm{D}(0.9)$ of the MFG was larger $(P<0.001)$ in milk from the udder half milked 4 times daily compared with milk from the udder half milked twice daily (Table 3 ). 
Table 2. Average milk yield, fat percentage, and fat yield per half udder in the control period and 2 or 4 times milking per day on half udder, respectively ${ }^{1}$

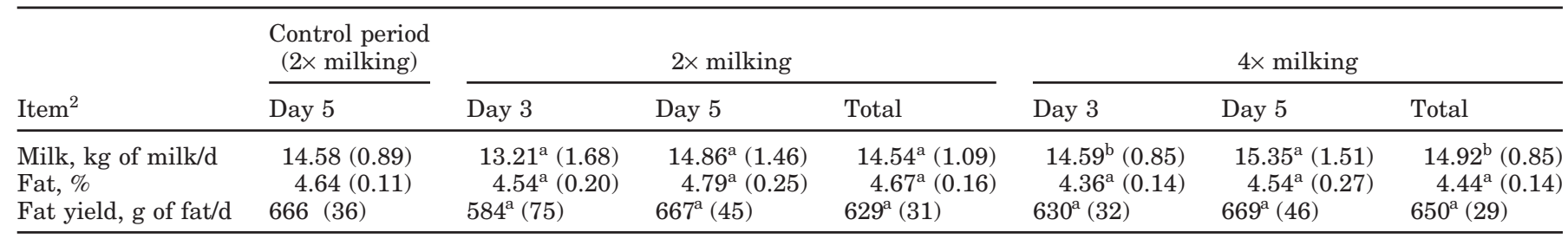

${ }^{a, b}$ Values within a row without a common superscript letter differ $(P<0.05)$ between milking frequencies.

${ }^{1}$ Values are means (SE) for 11 cows.

${ }^{2}$ Per udder half.

The MFG size increased with increasing fat yield for dairy cows (Wiking et al., 2004). Fat yield, however, did not increase in the present study. The increase in $\mathrm{D}(0.9)$, and not in $\mathrm{D}(0.1)$, after increased milking frequencies indicates that production of small-sized MFG is constant, whereas a shift to larger globules occurs for medium or larger fat globules. Large MFG are inherently more susceptible to lipolysis than smaller MFG (Wiking et al., 2003). This was confirmed in the present study, even though the increase in average MFG diameter was not so marked after increased milking frequency compared with the feed-induced increase in average diameter of MFG (Wiking et al., 2003).

\section{MFGM}

The MFGM protects the milk fat from lipolysis. Therefore, amount of membrane material is an important factor for the resistance of MFG to lipolysis. To quantify the amount of membrane material in milk, activity of $\gamma$-glutamyl transpeptidase was used as a marker. There was, however, no significant effect on the activity of $\gamma$-glutamyl transpeptidase after increased milking frequency, neither in total activity in whole milk nor when adjusted for fat content (Table 4). These results indicate that even though the secretory cells in the mammary glands must produce milk at a greater rate, production of MFGM material is sufficient to maintain a constant rate to cover the newly formed and

Table 3. Volume-weighted diameter $\left(\mathrm{d}_{(4,3)}\right)$ and 10 and 90 percentiles $[\mathrm{D}(0.1)$ and $\mathrm{D}(0.9)]$ in the control period and the following period with different milking frequency on half udder ${ }^{1}$

\begin{tabular}{|c|c|c|c|}
\hline Item & $\begin{array}{l}\text { Control period } \\
(2 \times \text { milking })\end{array}$ & $2 \times$ milking & $4 \times$ milking \\
\hline $\mathrm{d}_{(4,3)}, \mu \mathrm{m}$ & $4.21^{\mathrm{a}}(0.04)$ & $4.28^{\mathrm{a}}(0.06)$ & $4.36^{\mathrm{b}}(0.07)$ \\
\hline $\mathrm{D}(0.1), \mu \mathrm{m}$ & $2.13^{\mathrm{a}}(0.03)$ & $2.13^{\mathrm{a}}(0.04)$ & $2.14^{\mathrm{a}}(0.06)$ \\
\hline $\mathrm{D}(0.9), \mu \mathrm{m}$ & $6.83^{\mathrm{a}}(0.07)$ & $6.98^{\mathrm{b}}(0.11)$ & $7.15^{\mathrm{c}}(0.13)$ \\
\hline
\end{tabular}

larger MFG. This is presumably due to the fact that fat yield did not increase in the present study.

\section{Fatty Acid Composition}

Only the content of polyunsaturated fatty acids in milk was affected by increased milking frequency (Table 5). The proportion of polyunsaturated fatty acids was smaller $(P<0.01)$ in milk from the udder half milked 4 times compared with the other udder half milked twice daily, which, again, was less than that in the milk during the control period. These results clearly indicate that the de novo synthesis of milk fat was not affected by milking frequency because the proportion of $\mathrm{C} 4$ to $\mathrm{C} 14$ in milk was invariant between 2 and 4 times daily milking (Table 5). Our results agree with those of another study (Svennersten-Sjaunja et al., 2002) in which increased milking frequency did not change the fatty acid composition. To support the present results, it has been found that the enzyme activity of acetyl-CoA carboxylase and fatty acid synthetase, which are responsible for the de novo synthesis of milk fat in the mammary glands, is not greater in the udder half milked 4 times daily compared with the other udder half milked twice daily (Knight et al., 1992). In contrast, Hillerton et al. (1990) observed in a half udder experiment in dairy cows that the gland milked more frequently also had increased activity in milk synthesizing enzymes.

Average milking frequency in automatic milking systems is between 2.4 and 2.6 times daily (Svennersten-

Table 4. Activity of $\gamma$-glutamyl transpeptidase $\left(\Delta \mathrm{abs} \min ^{-1} \times 10^{-3}\right)$ in whole milk during the control and following period after different milking frequency of half udders ${ }^{1}$

\begin{tabular}{|c|c|c|c|}
\hline Item & $\begin{array}{l}\text { Control } \\
\text { period } \\
(2 \times \text { milking })\end{array}$ & $2 \times$ milking & $4 \times$ milking \\
\hline Total activity in milk & $364.1(9.8)$ & $371.7(16.9)$ & $368.8(14.6)$ \\
\hline Activity per $\mathrm{g}$ of milk fat & $15.9(0.43)$ & $16.2(0.73)$ & $15.9(0.74)$ \\
\hline
\end{tabular}

${ }^{1}$ Values are means (SE). 
Table 5. Fatty acid composition (wt\%) in the control period and the following period with different milking frequency on half udder ${ }^{1}$

\begin{tabular}{lcrr}
\hline Item & $\begin{array}{l}\text { Control period } \\
(2 \times \text { milking })\end{array}$ & $2 \times$ milking & $4 \times$ milking \\
\hline C4-14 & $28.22^{\mathrm{a}}(0.18)$ & $28.12^{\mathrm{a}}(0.29)$ & $28.30^{\mathrm{a}}(0.25)$ \\
C16 & $29.15^{\mathrm{a}}(0.35)$ & $29.15^{\mathrm{a}}(0.26)$ & $29.60^{\mathrm{a}}(0.28)$ \\
C18 & $11.11^{\mathrm{a}}(0.28)$ & $12.07^{\mathrm{a}}(0.38)$ & $11.97^{\mathrm{a}}(0.35)$ \\
Monounsaturated fatty acids & $26.34^{\mathrm{a}}(0.15)$ & $25.91^{\mathrm{a}}(0.21)$ & $25.53^{\mathrm{a}}(0.21)$ \\
Polyunsaturated fatty acids & $5.02^{\mathrm{a}}(0.07)$ & $4.74^{\mathrm{b}}(0.11)$ & $4.59^{\mathrm{c}}(0.11)$ \\
\hline
\end{tabular}

${ }^{\mathrm{a}-\mathrm{c}}$ Values within a row without a common superscript indicate significant differences between milking frequencies $(P<0.01)$.

${ }^{1}$ Values are means (SE) for 11 cows.

Sjaunja et al., 2000; Hogeveen et al., 2001; Petterson and Wiktorson, 2004). This frequency indicates that a majority of the cows are being milked $>2$ times daily. The present study confirms that milking frequency $>2$ times daily elevated FFA content in milk. Because enhanced milk yield in response to increased milking frequency is necessary to justify the cost of automatic milking systems, further research is needed to discover ways to improve the stability of MFG. For example, it has been reported that diets stimulating high de novo synthesis of milk fat reduce the content of FFA in milk (Wiking et al., 2003).

\section{CONCLUSIONS}

Size distribution of MFG in milk changes to larger globules when cows are more frequently milked. Consequently, increased amounts of FFA are detected after increased milking frequency because larger milk fat globules are more susceptible to lipolysis. Our study tends to reject the ideas that greater synthesis of shortchain fatty acids, insufficient MGFM production, or insufficient triglyceride synthesis causes the increased content of FFA in milk obtained from cows milked more frequently. Furthermore, our study shows that the increase in FFA content in milk after milking 4 times daily occurs by $5 \mathrm{~d}$ after increased milking frequency.

\section{ACKNOWLEDGMENTS}

We thank Ivan Nielsen and Stina G. Handberg for skilled technical assistance. Lennart Björck is acknowledged for critical evaluation of the manuscript. This work was financially supported by the Danish Dairy Research Foundation, the Danish Cattle Federation, and the Swedish Farmers Association.

\section{REFERENCES}

Ahrné, L., and L. Björck. 1985. Lipolysis and the distribution of lipase activity in bovine milk in relation to stage of lactation and time of milking. J. Dairy Res. 52:55-64.
Ayadi, M., G. Caja, X. Such, and C. H. Knight. 2003. Use of ultrasonography to estimate cistern size and milk storage at different milking intervals in the udder of dairy cows. J. Dairy Res. 70:1-7.

Ayadi, M., G. Caja, X. Such, M. Rovai, and E. Albanell. 2004. Effect of different milking intervals on the composition of cisternal and alveolar milk in dairy cows. J. Dairy Res. 71:304-310.

Bruckmaier, R. M., E. Rothenanger, and J. W. Blum. 1994. Measurement of mammary-gland cistern size and determination of the cisternal milk fraction in dairy-cows. Milchwissenschaft 49:543-546.

Cartier, P., Y. Chilliard, and D. Paquet. 1990. Inhibiting and activating effects of skim milks and proteose-peptone fractions on spontaneous lipolysis and purified lipoprotein lipase activity in bovine milk. J. Dairy Sci. 73:1173-1177.

deKoning, K., B. Slaghuis, and Y. van der Vorst. 2003. Robotic milking and milk quality: Efects on bacterial counts, somatic cell counts, freezing points and free fatty acids. Ital. J. Anim. Sci. 2:291-299.

Evers, J. M. J. 2004. The milk fat globule membrane-compositional and structural changes post secretion by the mammary secretory cell. Int. Dairy J. 14:661-674.

Hillerton, J. E., C. H. Knight, A. Turvey, S. D. Wheatley, and C. J. Wilde. 1990. Milk yield and mammary function in dairy cows milked four times daily. J. Dairy Res. 57:285-294.

Hogeveen, H., W. Ouweltjes, C. J. A. M. de Koning, and K. Stelwagen. 2001. Milking interval, milk production and milk flow-rate in an automatic milking system. Livest. Prod. Sci. 72:157-167.

IDF. 1991. Determination of free fatty acids in milk \& milk products. IDF Bull. 265. Int. Dairy Fed., Brussels, Belgium.

Jellema, A. 1986. Some factors affecting the susceptibility of raw cow milk to lipolysis. Milchwissenschaft 41:553-558.

Justesen, P., and M. D. Rasmussen. 2000. Improvements of milk quality by the Danish AMS self-monitoring programme. Pages 83-88 in Proc. Int. Symp. Robotic Milking, Lelystad, The Netherlands.

Klei, L. R., J. M. Lynch, D. M. Barbano, P. A. Oltenacu, A. J. Lednor, and D. K. Bandler. 1997. Influence of milking three times a day on milk quality. J. Dairy Sci. 80:427-436.

Klungel, G. H., B. A. Slaghuis, and H. Hogeveen. 2000. The effect of the introduction of automatic milking systems on milk quality. J. Dairy Sci. 83:1998-2003.

Knight, C. H., J. E. Hillerton, M. A. Kerr, R. M. Teverson, A. Turvey, and C. J. Wilde. 1992. Separate and additive stimulation of bovine milk yield by the local and systemic galactopoietic stimuli of frequent milking and growth hormone. J. Dairy Res. 59:243-252.

Lindqvist, B., T. Roos, and H. Fujita. 1975. Auto-analyzer determination of free fatty acids in farm milk. Modification of present method to simplify transportation of the sample. Milchwissenschaft 30:12-17.

Mather, I. H., and T. W. Keenan. 1998. Origin and secretion of milk lipids. J. Mammary Gland Biol. Neoplasia 3:259-273.

O'Brien, B., J. O'Connell, and W. J. Meaney. 1998. Short-term effect of milking interval on milk production, composition and quality. Milchwissenschaft 53:123-126.

Petterson, G., and H. Wiktorson. 2004. Illuminations or guiding light during night hours in the resting area of AMS-barns. Pages 468- 
473 in A better Understanding - Automatic Milking. A. Meijering, H. Hogeveen, and C. J. A. M. de Konig, ed. Wageningen Academic, Wageningen, The Netherlands.

Pirlo, G., G. Bertoni, and R. Giangiacomo. 2004 Introduction of AMS in Italian dairy herds: Effects on cow performances and milk quality in a herd of the Grana Padano area. Pages 335-340 in A better zunderstanding - Automatic Milking. A Meijering, $\mathrm{H}$. Hogeveen, and C. J. A. M. de Konig, ed. Wageningen Academic, Wageningen, The Netherlands.

Sapru, A., D. M. Barbano, J. J. Yun, L. R. Klei, P. A. Oltenacu, and D. K. Bandler. 1997. Cheddar cheese: Influence of milking frequency and stage of lactation on composition and yield. J. Dairy Sci. 80:437-446.

Shipe, W. F., G. F. Senyk, and K. B. Fountain. 1980. Modified copper soap solvent-extraction method for measuring free fatty acids in milk. J. Dairy Sci. 63:193-198.

Sjaunja, L.-O., L. Baevre, L. Junkarinen, J. Pedersen, and J. Setälä. 1990. A Nordic proposal for an energy corrected milk (ECM) formula. Pages 156-157 in Proc. 27th Biennial Session of the International Committee for Animal Recording. Paris, France.

Slaghuis, B. A., K. Bos, O. de Jong, A. J. Tudos, M. C. te Giffel, and C. J. A. M. de Koning. 2004. Robotic milking and free fatty acids. Pages 341-347 in A Better Understanding - Automatic Milking. A Meijering, H. Hogeveen, and C. J. A. M. de Konig, ed. Wageningen Academic, Wageningen, The Netherlands.

Stelwagen, K. 2001. Effect of milking frequency on mammary functioning and shape of the lactation curve. J. Dairy Sci. 84(E Suppl.):E204-E211.
Suhren, G., J. Hamann, W. Heeschen, and A. Tolle. 1981. On the influence of animal individual factors, the udder fraction and the milking interval on the content of free-fatty acids (FFA) in rawmilk. Milchwissenschaft 36:150-153.

Svennersten-Sjaunja, K., I. Berglund, and G. Pettersson. 2000. The milking process in an automatic milking system, evaluation of milk yield, teat condition and udder health. Pages 277-288 in Proc. Int. Symp. Robotic Milking, Lelystad, The Netherlands.

Svennersten-Sjaunja, K., S. Persson, and H. Wiktorsson. 2002. The effect of milking interval on milk yield, milk composition and raw milk quality. Pages V-43-V-48 in Proc. Int. Symp. The First North American Conference on Robotic Milking, Toronto, ON, Canada.

Tuckey, S. L., and J. Stadhouders. 1967. Increase in sensitivity of organoleptic detection of lipolysis in cows milk by culturing or direct acidification. Neth. Milk Dairy J. 21:158-162.

Wiking, L., L. Björck, and J. H. Nielsen. 2003. Influence of feed composition on stability of fat globules during pumping of raw milk. Int. Dairy J. 13:797-803.

Wiking, L., M. B. Frost, L. B. Larsen, and J. H. Nielsen. 2002. Effects of storage conditions on lipolysis, proteolysis and sensory attributes in high quality raw milk. Milchwissenschaft 57:190-194.

Wiking, L., J. Stagsted, L. Björck, and J. H. Nielsen. 2004. Milk fat globule size is affected by fat production in dairy cows. Int. Dairy J. 14:909-913.

Wiktorsson, H., K. Svennersten-Sjaunja, and M. Salomonsson. 2000. Short or irregular milking intervals in dairy cows-Effects on milk quality, milk composition and cow performance. Pages 128129 in Proc. Int. Symp. Robotic Milking, Lelystad, The Netherlands. 